\title{
ДИДАКТИЧНІ АСПЕКТИ ВИКОРИСТАННЯ ІКТ У ПРОФЕСІЙНІЙ ДІЯЛЬНОСТІ ВЧИТЕЛІВ СУСПІЛЬНО-ГУМАНІТАРНИХ ДИСЦИПЛІН
}

Подліняєва О. О. Дидактичні аспекти використання ІКТ у професійній діяльності вчителів суспільно-гуманітарних дисциплін.

У статті аналізуються основні дидактичні аспекти запровадження ІКТ у навчальний процес із суспільно-гуманітарних дисциплін, розкриваються специфічні особливості досягнення різних педагогічних цілей у навчанні з використанням вже наявних розробок, комплексів $\mathrm{i}$ комплектів комп'ютерного обладнання.

Ключові слова: інформаційно-комунікаційні технології, комп'ютерна модель, педагогічна система.

Подлиняева О.А. Дидактические аспекты введение ИКТ в обучении общественногуманитарных дисциплин

В статье анализируются основные дидактические аспекты внедрения ИКТ в учебный процесс с общественно-гуманитарных дисциплин, а также раскрываются специфические особенности решения различных педагогических целей в обучении с использованием уже имеющихся разработок, комплексов и комплектов компьютерного физического оборудования.

Ключевые слова: Информационно-коммуникационные технологии, компьютерная модель, педагогическая система.

Podlinayeyva O. O. Didactic aspects of introduction of ict in teaching of history and social science.

In the article are analyzed the main aspects of introduction of ICT in the learning process in history and social science, and also the specific features of the solution of various pedagogical aims are opened in studies with the use of already present developments, complexes and complete sets of computer equipment.

Key words: ICT, computer model, educational system.

3-поміж основних сучасних напрямів та завдань покращення й удосконалення системи освіти, що окреслені національною програмою відродження освіти в Україні, запровадження ефективних сучасних технологій та новітніх досягнень i, зокрема, засобів інформаційних комунікативних технологій (IКТ) у методичному забезпеченні навчального процесу $є$ однією 3 найбільш вагомих проблем системи освіти, а іiі вдосконалення, орієнтація на розвиток індивідуальності й особистісного розвитку кожного учня, творчості учнів з урахуванням здібностей кожного з них є досить актуальною дидактичною проблемою.

IKT, як засіб навчання, мають певні дидактичні функції. Вони незамінні на стадії чуттєвого сприйняття досліджуваних об'єктів і явищ. При цьому наочні образи забезпечують постійний зв'язок мислення 3 досліджуваним об'єктом (через абстрактне мислення). Для більш повного запам'ятовування і засвоєння навчального матеріалу учнями необхідно задіяти якомога більшу кількість каналів сприйняття інформації, що ефективно досягається застосуванням графічних і мультимедійних можливостей комп'ютера. Отже, ІКТ становлять сукупність методів і засобів накопичення, оброблення, подання, збереження і передавання інформації. Однак учителю, плануючи урок із застосуванням IКТ, необхідно зважувати таку доцільність для вивчення історичного матеріалу та дотримуватися певних дидактичних вимог, відповідно до яких ІКТ повинні бути органічно взаємопов'язаними з іншими складниками процесу навчання: цілями, змістом, формами, методами, діяльністю вчителя й учня. Роль учителя $\epsilon$ ключовою у формуванні інформаційної культури учнів. Увага учнів, рівень засвоєння ними отримуваних знань залежать від уміння вчителя правильно організувати заняття. Робота повинна передбачати наявність зворотного зв'язку.

Переваги використання IКТ у викладанні суспільно-гуманітарних дисциплін нині зумовлюють палкі суперечки різних зацікавлених сторін: учителів, методистів, батьків. Однак оскаржити той факт, що комп'ютерні технології, які набагато швидше входять у життя 
сучасних дітей, ніж у життя школи, набагато полегшують, як роботу педагога, так і навчання дітей, буває часом складно.

Роль ІКТ в історичній освіті може бути, на наш погляд, різноманітною:

- допомога учням в ефективному засвоєнні історичної інформації та її систематизації;

- надання учням максимальних можливостей свободи у визначенні способів і темпів засвоєння програмного матеріалу;

- сприяння становленню об'ємних і яскравих уявлень про минуле;

- моделювання соціальних процесів, особливо у зв'язку із зростанням інтересу до проблеми альтернативного історичного процесу.

Практична значимість використання ІКТ у викладанні суспільно-гуманітарних дисциплін:

- інноваційний підхід у вивченні історії створює умови для формування теоретичного мислення учнів;

• підвищення мотивації вивчення предмету історії;

- підвищення якості засвоєння історії.

На межі XX-XXI століть з'являється методична література, яка висвітлює можливості вибору джерел інформації, застосування інформаційних технологій у викладанні історії. Це питання досліджують зарубіжні дослідники В. Боголюбов, І. Захарова, М. Короткова, М. Студенікін. Питання методики викладання історії із використанням комп'ютерних та мультимедійних технологій в історико-методичній літературі майже не розглянуті, за винятком певної кількості статей у педагогічній пресі, зокрема П. Гевала, В. Недзельської, О. Охредька, Л. Фоменко.

Мета статті полягає в тому, щоб проаналізувати основні дидактичні аспекти запровадження IКТ у навчанні суспільно-гуманітарних дисциплін та основні проблеми, які виникають під час їх використання в навчальному процесі.

У недалекому минулому інформацію з будь-якого предмета чи теми учень міг отримати 3 підручника, довідкової літератури, лекції або пояснення вчителя, конспекту уроку. Нині, 3 огляду на сучасні реалії, учитель повинен використовувати нові методи роботи, спираючись на IKT. Якщо в рамках знаннєвої моделі навчання історії найважливішим завданням було сформувати в учня цілісну картину життя суспільства в часово-просторовому вимірі, то в рамках компетентнісної моделі це бажане навчальне завдання. За наявності інших важливих складників його реалізація може забезпечити високий рівень компетентності в галузі. Цими іншими складниками, попри знання, є відповідні вміння, навички й досвід використання інформації, зокрема історичної. Для педагогів - учителів суспільно-гуманітарних дисциплін, зокрема, постає завдання такого формування знань і вмінь, такої організації навчальновиховного процесу, аби набуті знання й уміння слугували орієнтиром і основою їх подальшого використання як у начальній діяльності, так і з метою планування і здійснення іншої трудової діяльності. Активне використання інформаційно-комунікаційних технологій під час викладання шкільного курсу суспільно-гуманітарних дисциплін дозволяє ефективніше впливати на розвиток особистості учнів. Це сприяє впровадженню новітніх особистісно орієнтованих освітніх технологій, диференціації навчально-виховного процесу, задоволенню запитів і потреб, розкриттю творчого потенціалу. Водночас зазначене сприяє розвитку життєвих компетенцій і науково-технологічної культури учнів, що нині є невіддільним складником загальної культури кожної людини і суспільства в цілому.

Стрімкий розвиток інноваційних педагогічних технологій i, зокрема, IКТ, спровокував також різке збільшення кількості різноманітних ППЗ. Подібні тенденції мають у собі подвійний вплив: позитивним моментом $є$ можливість вибору вчителем найбільш вдалого програмного продукту, який повною мірою міг би задовольнити покладені на нього педагогічні і психологічні завдання. Проте $\epsilon$ і негативні моменти: по-перше складність цього вибору. У зв'язку з цим дуже важливим є вміння педагога розібратись у тому розмаїтті ІКТ, які існують на ринку і пропонуються в Інтернеті. Умовно IКТ представлені електронними засобами навчального призначення (ЕЗНП), педагогічними програмними засобами (ППЗ) навчання, мережею Інтернет, ресурсами текстового редактора Microsoft Word (з його програмними продуктами - Microsoft: Publisher, Word, Excel, Internet Explorer) тощо. Зрозуміло, що краще використовувати ті ІКТ, які мають гриф МОН України, оскільки вони пройшли апробацію й експертну психолого-педагогічну оцінку; дизайн-ергономічну; техніко-технологічну оцінку провідними фахівцями. Принципи організації навчального процесу 3 використанням 
електронних засобів навчання відображено в наказах МОН «Про правила використання комп’ютерних програм у навчальних закладах» [5], постанові Кабінету Міністрів Україні «Про затвердження Державної програми «Інформаційні та комунікаційні технології в освіті та науці» [2]. Якщо для розкриття теми уроку необхідно використати матеріал з Інтернету, то, оцінюючи його, слід звертати увагу на те, щоб освітне електронне видання або ресурс відповідав дидактичним і методичним вимогам» $[8,52]$.

Зокрема, Г. Лаврентьєва пропонує такі вимоги до електронних засобів навчального призначення (ЕЗНП):

- Вимога науковості навчання з використанням ЕЗНП означає достатню глибину, коректність і наукову вірогідність викладення змісту навчального матеріалу, наданого ЕЗНП 3 урахуванням останніх наукових досягнень.

- Доступності навчання, здійснюваного з використанням ЕЗНП, означає необхідність визначення рівня теоретичної складності і глибини вивчення навчального матеріалу згідно вікових та індивідуальних особливостей учнів. За цих обставин неприпустимою $є$ надмірна ускладненість і перевантаженість навчального матеріалу, за якої оволодіння матеріалом стає непосильним для опанування.

- Забезпечення проблемності навчання. що обумовлено самою сутністю і характером навчально-пізнавальної діяльності. Коли учень зіштовхується 3 навчальною проблемною ситуацією, що вимагає розв'язання, його розумова активність зростає. Рівень виконання даної дидактичної вимоги за допомогою ЕЗНП може бути значно вищим, ніж за використання традиційних інформаційних засобів: підручників і посібників.

- Забезпечення наочності навчання. Зазначена вимога у випадку ЕЗНП реалізується на принципово новому, більш високому рівні. Поширення систем віртуальної реальності дозволяє в найближчому майбутньому говорити не тільки про наочність, але і про полісенсорність навчання.

- Забезпечення свідомості навчання, самостійності й активізації пізнавальної діяльності припускає забезпечення навчальним матеріалом самостійних дій учнів із використанням навчальної інформації у випадку чіткого розуміння кінцевих цілей і завдань навчальної діяльності. При цьому усвідомленням для учня $є$ той зміст, на який спрямовано його навчальну діяльність.

- Вимога систематичності й послідовності навчання у використанні ЕЗНП означає забезпечення послідовного засвоєння учнями визначеної системи знань й опанування конкретними уміннями й навичками у досліджуваній предметній галузі. Необхідно, щоб знання, уміння й навички формувалися у визначеній системі, у логічному порядку [3].

Нині програмного забезпечення, придатного для систематичного використання у процесі навчання предметам суспільно-гуманітарного циклу в Україні, недостатньо. Необхідно підкреслити, що комп'ютерна підтримка підручника як засобу посилення функціональності змісту і забезпечення мотивації навчання є вкрай необхідною. У класифікації електронних засобів навчання О. Башмакова $[1,24]$ електронний підручник як основне електронне видання, створене на високому науковому і методичному рівнях, відноситься до першого класу електронних засобів навчання - засобів теоретичної і технологічної підготовки [7]. Електронний підручник чи посібник виконує такі ж дидактичні завдання, як і традиційний. Але водночас він має низку переваг. Головною 3 них $\epsilon$ застосування мультимедіа, що дає можливість відтворювати візуальну та аудіоінформацію (кінохроніку, уривки з художніх та документальних кінофільмів, анімаційні діаграми, карти та схеми, інтерактивні таблиці, а також музику, будь-який звуковий супровід). Зрозуміло, що такий навчальний матеріал учень сприймає з більшим зацікавленням, що активізує навчальний процес, заохочує школярів до поглиблення знань і набуття нових умінь.

Водночас варто зазначити, що актуальною є проблема у використанні таких посібників: майже всі комп'ютерні навчальні програми 3 історії розраховані на індивідуальне опрацювання. Відео- та фотодокументи, розміщені у таких електронних підручниках, неможливо використовувати на уроках у предметних кабінетах, обладнаних особистим ноутбуком учителя й декількома демонстраційними моніторами - вони мають малий формат, а система захисту не дозволяє вилучити їх з електронного носія для збільшення на весь екран.

Проте вибір програмного забезпечення - це не єдина проблема, яка постає перед учителями суспільно-гуманітарних дисциплін в умовах сучасного інформаційного суспільства. 
Однією з таких проблем є вибір джерел достовірної та якісної інформації, оскільки за браком часу та організаційно-педагогічних умов не завжди видається можливим оперативно перевірити достовірність інформації, отриманої 3 мережі Інтернет. Єдиним варіантом залишається обрати Інтернет-ресурси, які відповідають поставленим вимогам до науковості матеріалу та використовувати наявні матеріали у процесі підготовки до занять $[8,53]$.

Зазначимо, що з розвитком технологій Web 2.0 використовувати інформацію 3 таких мереж стає все більш ризиковано. На базі Web 2.0 - користувач є співрозробником, і співавтором. Позитивним моментом є скасування сторонньої регламентуючої сторони (модерації), це провокує користувачів слідкувати за помилками один одного, а також швидко вносити зміни; негативним $\epsilon$ відсутність гарантій, що запропонований матеріал відповідає поставленим вимогам, оскільки відсутня жодна відповідальність авторів за інформацію, яку вони публікують, оскільки неможливо однозначно визначити, хто є іiі автором. Найбільш організованою й достовірною вважається Інтернет база даних Wikipedia, хоча незважаючи на оперативність спільноти авторів та модераторів, будь-який користувач може внести зміни, тим самим спотворивши зміст та дезінформувавши користувачів, які будуть впевнені в достовірності даних. Відтак вибір джерел інформації та підготовка на їх основі матеріалів до заняття, вимагає достатньої компетентності вчителя (викладача).

Аналогічний висновок можна зробити стосовно тих учнів, які активно користуються мережею Інтернет для підготовки до уроків. Як показують дослідження провідних компаній, i зокрема Microsoft та Intel $[6,18]$ : учителі загальноосвітніх навчальних закладів констатують, що якість шкільних рефератів протягом останніх років помітно погіршилася: інформація, яка міститься у більшості рефератів, є недостовірною, неповною або застарілою. Проте часто учні не замислюються над достовірністю отриманої інформації, не вміють аналізувати та узагальнювати іiі, оскільки у них відсутне або недостатньо розвинуте критичне мислення. Якщо у процесі підготовки рефератів недостовірна чи неправдива інформація до життєвого ризику не призводить, то у випадку пошуку інформації, що може вплинути на фізичне здоров'я, ризик істотно збільшується. В Інтернеті на різноманітних форумах досить легко знайти інформацію, яка $є$ не лише антинауковою, а й життєво небезпечною, якщо нею скористатися.

Використання інформаційних технологій може допомогти вчителю в реалізації цілей різноманітних педагогічних технологій. Зокрема технологія навчання у співробітництві значною мірою може бути реалізованою під час групової роботи з використанням комп'ютера i інших технічних засобів. При цьому ії учасники можуть виконувати як однотипні завдання, взаємно контролюючи або замінюючи один одного, так і окремі етапи загальної роботи. У процесі виконання завдань у парах або групах не потрібно однакового рівня володіння технічними засобами, у процесі спільної роботи відбувається і вдосконалення практичних навичок більш «слабких» у цьому відношенні учнів. Усі члени робочої групи зацікавлені в загальному результаті, тому неминуче і взаємонавчання не тільки з предмету проекту, але і 3 питань ефективного використання обчислювальної техніки та відповідних інформаційних технологій. Навчання у співробітництві з використанням інформаційних та комунікаційних технологій не вимагає безпосередньої присутності учасників групи, робота може проводитися дистанційно, з передаванням матеріалів і взаємним спілкуванням за допомогою послуг Інтернету. Диференційований підхід до навчання також може бути реалізованим із використанням сучасних інформаційних технологій. Учитель формулює тему проекту 3 урахуванням індивідуальних інтересів і можливостей учня, заохочуючи його до творчості. У цьому випадку учень має можливість реалізувати свій творчий потенціал, самостійно обираючи форму подання матеріалу, спосіб і послідовність його викладу. Комп'ютерне тестування, як і будь-яке тестування, також надає змогу індивідуалізувати та диференціювати завдання шляхом різнорівневих запитань. До того ж тести на комп'ютері дозволяють повернутися до невідпрацьованих питань і виконати «роботу над помилками».

Метод проектів повністю реалізується в мультимедійних презентаціях та інших комп'ютерних проектах. Як уже згадувалося вище, подібні проекти можуть бути виконані за допомогою інформаційних технологій (тут, до речі, неоціненну допомогу може надати Інтернет). Робота над проектом спонукає учня не тільки до глибокого вивчення будь-якої теми курсу, але і до засвоєння нових програм і програмних продуктів, використанню новітніх інформаційних і комунікаційних технологій. 
Використання IКТ як на уроках суспільно-гуманітарних дисциплін, так і в позаурочній діяльності учнів $є$ одним 3 найперспективніших напрямків розвитку сучасної науки. Окрім цього необмежені можливості ІКТ щодо надання інформації розв'язують проблему постійної зміни й оновлення змісту шкільної історичної освіти. Важливою умовою запровадження ІКТ у навчання суспільно-гуманітарних дисциплін, на нашу думку, є те, що всі прийоми, які успішно розроблені у вітчизняній дидактиці, не повинні бути відкинуті й забуті, а якісно удосконалені на основі використання ІКТ задля підвищення пізнавальної активності учнів на уроках історії, що є однією із цілей учителя на уроці. Сучасні педагогічні технології у поєднанні з сучасними інформаційно-комунікаційними технологіями можуть істотно підвищити ефективність освітнього процесу, розв'язати поставлені перед освітньою установою завдання виховання всебічно розвиненої, творчо вільної особистості.

Аналізуючи проблеми, які виникають за використання IКТ у навчальній діяльності 3 суспільно-гуманітарних дисциплін, можна зробити висновок, що бажання використовувати та запроваджувати новітні технології в навчальний процес із суспільно-гуманітарних дисциплін це виключно ініціатива і бажання конкретного вчителя (викладача), який самостійно розв'язує чи доцільно використовувати інноваційні розробки під час демонстрацій чи пояснення нового матеріалу. Адже в програмах з суспільно-гуманітарних дисциплін жодним чином цей чинник не регламентується. Використання ІКТ під час викладання суспільно-гуманітарних дисциплін вимагає від учителя дотримання певних дидактичних вимог:

- чітко визначати педагогічну мету застосування IКТ у навчальному процесі;

- уточнювати, де і коли вчитель застосовує ІКТ у контексті логіки розкриття навчального матеріалу і своєчасності подання конкретної інформації;

- погоджувати обрання засобів IКТ з іншими засобами, що застосовуються на уроці;

- ураховувати специфіку навчального матеріалу, особливості класу, характер пояснення нової інформації;

• аналізувати й обговорювати з класом найбільш важливі, вузлові питання досліджуваного матеріалу.

Отже, використання нових інформаційних технологій і застосування нетрадиційних методик навчання може здійснити помітний вплив на формування практичних умінь і навичок учнів у засвоєнні історичного матеріалу.

Найбільший ефект від ознайомлення фахівця з елементами нових вирішень слід очікувати тоді, коли він сам індивідуально, залежно від власних переконань та уявлень, опановує нові ідеї і пропозиції й самостійно співвідносить їх зі своїми власними баченнями можливості оцінки та впровадження у власну практичну діяльність. Досить важливим у професійній перепідготовці вчителя суспільно-гуманітарних дисциплін $\epsilon$ ознайомлення його 3 усіма можливими варіантами і прикладами запровадження засобів IКТ у навчально-виховний процес iз суспільно-гуманітарних дисциплін і розкриття специфічних особливостей конкретних прикладів досягнення різних дидактичних цілей у навчанні з використанням вже наявних розробок та комплексів і комплектів, які ще не розкрито в методиці навчання або недостатньо опрацьовано, не доведено до остаточного розв'язання, натомість пропонуються вчителю для запровадження в його практичній педагогічній діяльності.

\section{Література}

1. Башмаков А. И. Разработка компьютерных учебников и обучающих систем: [монографія] / А. И. Башмаков, И. А. Башмаков. - М. : Информационно- издательский дом «Филинъ», 2003. - 616 с. 2. Кабінет Міністрів України. Постанова. Програма. Заходи. Від 07.12.2005 № 1153. Про затвердження Державної програми «Інформаційні та комунікаційні технології в освіті і науці» на 2006-2010 роки. - Режим доступу: http://zakon.rada.gov.ua/cgi-bin/laws/main.cgi?nreg=1153-2005-\%EF. 3. Лаврентьєва Г. П. Методи та підходи до організації науково-педагогічного дослідження оцінювання якості електронних засобів навчання [Електронний ресурс] / Г. П. Лаврентьєва // Інформаційні технології і засоби навчання: електронне наукове фахове видання / Ін-т інформ. технологій і засобів навчання АПН України, Ун-т менеджменту освіти АПН України; гол. ред.: В. Ю. Биков. - 2009. - № 2(10). - Режим доступу: http://www.nbuv.gov.ua/e-journals/ITZN/em10/emg.html 4. Ладиченко T. Електронний педагогічний програмний засіб з історії - новий крок в оволодінні навчальним матеріалом // Історія в школах України. - 2005. - №4. 5. Міністерство освіти і науки України. Наказ. м. Київ. № 903 від 02 грудня 2004р. Про затвердження Правил використання комп'ютерних програм у навчальних закладах. - Режим доступу : http://www.mon.gov.ua/laws/MON_903.doc. 6. Морзе Н. В. 
Підготовка педагогічних кадрів до використання комп'ютерних телекомунікацій / Н.В. Морзе // Комп’ютерно-орієнтовані системи навчання. Вип. 6. - Київ: НПУ ім. М.П. Драгоманова, 2003. - С. 12-25. 7. Про затвердження Порядку надання навчальній літературі, засобам навчання і навчальному обладнанню грифів та свідоцтв Міністерства освіти і науки України. Наказ Міністерства освіти і науки України від 17 червня 2008 року № 537. - Режим доступу: http://www.ukrbook.net/zakony/N_537.htm. 8. Худобець О.А. Чому Інтернет потрібний вчителеві історії / О. А. Худобець //Історія. - 2005. - №5-6. - С. 52-56.

УДК 378.011.3-051:7.071(477)

Олена Пономарьова

\section{ІНТЕГРАЦІЯ В СИСТЕМІ ПІДГОТОВКИ ФАХІВЦІВ МИСТЕЦЬКИХ СПЕЦІАЛЬОСТЕЙ У ВИЩИХ НАВЧАЛЬНИХ ЗАКЛАДАХ УКРАЇНИ}

Пономарьова О. М. Інтеграція в системі підготовки фахівців мистецьких спеціальностей у вищих навчальних закладах України

У статті вища мистецька освіта розглядається як поліінтегрована професійно-педагогічна система підготовки фахівців мистецьких спеціальностей у вищих навчальних закладах України, спрямована на збереження, відтворення та примноження суспільно-культурних, культурно-мистецьких, творчо-мистецьких, творчо-виконавських, мистецько-педагогічних, художньо-проектних, естетико-виховних, художньо-естетичних та просвітницьких традицій світової та української культури.

Ключові слова: фахівці мистецьких спеціальностей, мистецтво, вища мистецька освіта, інтеграція, поліінтеграція.

Пономарева Е.Н. Интеграция в системе подготовки специалистов в сфере искусства в высших учебных заведениях Украины.

В статье высшее художественное образование рассматривается как полиинтеграционная профессионально-педагогическая система подготовки специалистов художественных специальностей в высших учебных заведениях Украины, которая направлена на сохранение, воссоздание и приумножение общественно-культурных, культурно-художественных, художественнотворческих, исполнительских, художественно-педагогических, художественно-проектных, эстетико-воспитательных и просветительских традиций мировой и украинской культуры.

Ключевые слова: специалисты в сфере искусства, искусство, высшее образование в сфере искусства, интеграция, полиинтеграция.

Ponomaryova O. M. Integration is in the system of arts specialists training in higher educational establishments of Ukraine.

Higher artistic education is seen by us as a polyintegrated professional and pedagogical system of art specialists training in higher educational institutions of Ukraine aimed at preservation, restoration and augmentation of socio-cultural, cultural and artistic, creative and artistic, creative and performing, artistic and educational, art and design, aesthetic and educational, artistic and aesthetic and educational traditions of world and Ukrainian culture.

Key words: art specialists, art, higher professional arts education, integration, polyintegration.

Освіта в галузі мистецтва $є$ складною, відкритою до змін, розгалуженою системою впровадження професійно-мистецьких, художньо-творчих, ціннісно-естетичних, культурнопросвітницьких, народно-аматорських досягнень у теорію і практику навчально-виховного процесу, спрямованого на здобуття особистістю знань, навичок, умінь і компетенцій професійномистецького, мистецько-педагогічного, художньо-творчого, художньо-виконавського, художньоестетичного спрямування відповідно до завдань різних освітніх і освітньо-кваліфікаційних рівнів підготовки фахівців мистецьких спеціальностей.

Підготовка фахівців мистецьких спеціальностей у вищих навчальних закладах України $є$ процесом і результатом цілеспрямованої професійної художньо-творчої діяльності, культурномистецької практики у поєднанні із теоретичним осягненням закономірностей соціуму, культури, мистецтва і буття відповідно до теоретико-концептуальних основ філософії, 